\title{
A Study on Construction Project Managers' Temperament Qualities
}

\author{
Chenhua Cui \\ School of architecture, Xianyang Vocational Technical College, No 1 tongyi Road, Fengwei New \\ District, Xianyang City, Shaanxi Province, China. \\ 1449202824@qq.com.
}

\begin{abstract}
Keywords: Construction Project Manager; Temperament; Qualities; Analytic hierarchy process (AHP) ; Questionnaire survey method; Study
\end{abstract}

\begin{abstract}
Under the circumstances of more and more surging upward in construction field, if want to successfully ensure the quantity, quality and safety of each construction engineering project, this requires that our construction project managers constantly strengthen their connotation construction and qualities' training. On the basis of attention to the construction project manager for many years, I have felt the importance of temperament qualities of the construction project manager for his employment and career success. Therefore from the psychological discipline angle, using the method of AHP, the network interview, questionnaire investigation, informal discussion, visit, data collection method and other methods, considering the construction project management practices, I deeply analyze the temperament qualities and related issues of the construction project manager, build up the temperament formula of the construction project manager, obtain "how to mold the temperament qualities which construction project manager should have".
\end{abstract}

\section{Introduction}

Through reading massive literature materials and own social practice construction engineering project management reality, find that a research on project manager temperament is very few at home and abroad from ancient to present, then, the research on temperament qualities of the construction project manager is more rare. I hope my analysis and exploration can fill this domain. I wish I can make due contributions for improving the quality of the construction project manager and selection of the construction project manager. [1]

\section{The Connotation of Temperament and the Cause of the Research on Construction Project Managers' Temperament Qualities}

The Connotation of Temperament. Temperament derived from Latin, its original meaning is mix, blend, later is used to describe people excited, emotional, moody psychological characteristics. It is often said that the temper, natural disposition. In modern psychology temperament is defined as: Temperament is manifested as typical and stable dynamic characteristics of the psychological activity and behavioral aspects. Understanding of the definition should be paid attention to the following four points.

Firstly, temperament is the external dynamic characteristics of individual psychological activity and behavior, mainly manifest characteristics of the psychological activity of speed, strength, stability and directivity. Power refers to speed, strength, stability, internal and external orientation of psychological process and so on, it makes personal color on all psychological activity. [2]

Secondly, temperament as the dynamic characteristics of persons' psychological activities, it has nothing to do with the content and motivation of the persons' psychological activities, namely the temperament characteristics generally is not affected by the purpose of personal activity, motives and content, it has strong stability. It can make people's psychological activity infected with a specific color, form a unique style.

Thirdly, temperament is greatly influenced by innate biological factors, namely the congenital factor occupies the main status. Temperament is mainly affected by the nervous system type. [3]

Fourthly, temperament has certain plasticity. Although temperament is congenital, but does not 
mean it doesn't change completely, Under the conditions of life and education, under the guise of the character, temperament can be considerable improved.

Cause of the Research on Construction Project Managers' Temperament Qualities. 1. It is of great significance and role for the construction project manager's career choice and the work allocation.

Although temperament do not affect active the nature, but can affect the efficiency of activities. If in the study, the work, the life considering this point, can effectively improve the efficiency of themselves and others. Relating to our architectural engineering project management, selecting the temperament appropriate personnel for construction project manager job, can obviously improve the work efficiency, reduce mistakes, it is helpful for successful and effectively completion of each building project. [4]In the special occupation of construction project manager, the many clues, the heavy shoulder pole, the tight duty, the outside high expects create his body and mind to have to be highly anxious frequently. So the status quo puts forward specific requirements for the temperament characteristics of the class of people, for example, he must have extremely sensitive response, willingness to take risks and crisis. Under the circumstances, temperament characteristics influences whether a person is suitable for the career. So employer shall determine the temperament characteristics in the selection and training of such professional personnel. [5] This is a basis for the occupation choice and elimination.

2. The construction project manager's temperament quality is indispensable important constituent in the quality structure system of construction project manager. Research on the construction project manager's quality structure has to be clearly analyzed his temperament quality.

3. In the construction project manager's training and education, temperament characteristics provides us the basis of teaching students in accordance with their aptitude. We only understand the temperament characteristics of each construction project manager, and according to these characteristics to take different education means and methods, therefore can obtain good education effect. [6]

\section{Empirical Exploration}

This investigation and survey mainly through the questionnaire survey, the coordinate enterprise visits, visit of walk (letter) for frontline's construction technical personnel, the conference exchanges, individual interviews or any other means. During the research fully launched this professional full-time teachers and part-time teachers, and mobilized enterprises to actively participate in research work. Visited enterprise of 75 units, provided questionnaire total 465 parts, the returns-ratio is $98 \%$. Interview object involves the government leading, enterprise general manager, chief engineer, enterprise human resources department leaders, project managers, frontline staff, graduate and so on. From the numerous construction projects Manager's temperament testing I sorted out the temperament test as follows in table 3 (the norm is moderate). This test contains 60 questions, the purpose is to know the temperament types and assigned appropriate jobs. Reply these questions should be realistic, how wants how to reply, don't have to do more consideration, because there is no standard answer and good or bad. [7]

Please assign points after see the topic, think it most fit for oneself situation to record 2 points; better fit for oneself situation to record 1 point; record 0 between conformity and unconformity, better unfit for oneself situation to record -1 point; completely unfit for oneself situation to record -2 point.

Question number of choleric temperament type: 269141721273136384248505458

Question number of sanguine temperament type: 4811161923252934404446525660

Question number of phlegmatic temperament type: 1710131822263033394345495557

Question number of melancholic temperament type: 3512152024283235374147515359

See total score of each temperament type. If the score of a kind of temperament is higher 4 points than that of other three, the person can be classified as a person of the temperament type. In addition the score of the temperament is over 20 points, the person can be classified as a person of the 
typical type. If the score between 10 to 20 points, the person can be classified as a person of the general type. If score difference of two kinds of temperament is less than 3 points, and obviously is higher than other two kinds to reach above 4 points, the person can be judged to be two types of hybrid; similarly, if score of three temperament is higher than score of the fourth temperament, moreover very close, the person can be judged to be three kinds of hybrid. [8] Summarize and conclude: construction project manager's temperament is taking the choleric type as first and guidance, sanguine type is normalizing (namely long-term throughout the work and life), When need to calmly and earnestly ponder should manifest the phlegmatic and the few melancholic type.

Table 1 The construction project manager's temperament questionnaire

\begin{tabular}{|c|c|c|c|}
\hline $\mathrm{n}$ & content & $\mathrm{n}$ & content \\
\hline 1 & work safely, do not make the uncertain matter & 31 & would rather talk than whisper \\
\hline 2 & $\begin{array}{l}\text { meeting exasperating thing is anger, only } \\
\text { speaking heartfelt wishes can be happy }\end{array}$ & 32 & people say I'm always unhappy \\
\hline 3 & $\begin{array}{l}\text { would rather a person doing things than very many } \\
\text { people in the same place }\end{array}$ & 33 & understanding the problem often slower than others \\
\hline 4 & quickly adaptation to a new environment & 34 & $\begin{array}{l}\text { as long as a short rest when tired can fiddle, back to } \\
\text { work }\end{array}$ \\
\hline 5 & $\begin{array}{l}\text { weary of intense stimulation, such as scream, } \\
\text { noise, danger, lens }\end{array}$ & 35 & $\begin{array}{l}\text { would rather think confidence, reluctant to speak out } \\
\text { it }\end{array}$ \\
\hline 6 & $\begin{array}{l}\text { quarrel with people, always a pre-emptive strike, } \\
\text { like provocation }\end{array}$ & 36 & $\begin{array}{l}\text { as soon as possible to achieve settled goal, not reach } \\
\text { the goal never give up }\end{array}$ \\
\hline 7 & enjoy a quiet environment & 37 & $\begin{array}{l}\text { the same study, work with others after a period of } \\
\text { time, often more tired than other people }\end{array}$ \\
\hline 8 & like associating with the human & 38 & $\begin{array}{l}\text { do thing boldly, often without thinking about the } \\
\text { consequence }\end{array}$ \\
\hline 9 & envy people who is good at control his emotions & 39 & $\begin{array}{l}\text { when someone teaches new knowledge and } \\
\text { technology, always hope he speaks slowly, repeat }\end{array}$ \\
\hline 10 & life regular, rarely violating schedule & 40 & can quickly forget the unpleasant things \\
\hline 11 & in most cases the mood is optimistic & 41 & $\begin{array}{l}\text { do homework or complete a job always spend more } \\
\text { time than others }\end{array}$ \\
\hline 12 & think restricts very much encountering a stranger & 42 & $\begin{array}{l}\text { like heavy strenuous activities, or participate in } \\
\text { various cultural and sports activities }\end{array}$ \\
\hline 13 & encounter an irritating, self-restraint well & 43 & cannot get attention from one thing to another thing \\
\hline 14 & works always has the exuberant energy & 44 & after accepting a task, just hope solve it quickly \\
\hline 15 & encounter problems often ambivalent, indecisive & 45 & think conformist stronger than risk \\
\hline 16 & never felt too much restrictive in the crowd & 46 & can simultaneously pay attention to several things \\
\hline 17 & $\begin{array}{l}\text { when mood soaring, feel interesting does } \\
\text { anything, when mood low, feel meaningless does } \\
\text { anything }\end{array}$ & 47 & when I am annoyed, others is hard to make me happy \\
\hline 18 & $\begin{array}{l}\text { when focused on one thing, other things are } \\
\text { difficult to distract me }\end{array}$ & 48 & like watching plot ups and downs exciting stories \\
\hline 19 & understanding problem always faster than others & 49 & conscientious, consistent attitude about work \\
\hline 20 & face not liking things to never say to others & 50 & can't get along very well with the surrounding people \\
\hline 21 & memory ability is strong & 51 & $\begin{array}{l}\text { like reviewing the learned knowledge, repeat already } \\
\text { grasped work }\end{array}$ \\
\hline 22 & can long time do boring and monotonies' thing & 52 & $\begin{array}{l}\text { likes doing work in a big changes and more kinds of } \\
\text { work }\end{array}$ \\
\hline 23 & $\begin{array}{l}\text { a thing conforms to the interest done full of } \\
\text { vigor, otherwise does not want to do }\end{array}$ & 53 & $\begin{array}{l}\text { I as if compared to others clearly remembered } \\
\text { poetry childhood could carry }\end{array}$ \\
\hline 24 & a minor matter can cause the mood undulation & 54 & someone said I "language hurt", but I don't think so \\
\hline 25 & hate to do that requires patience, careful work & 55 & in study and life, fall behind often due to slow \\
\hline
\end{tabular}




\begin{tabular}{|l|l|c|l|}
\hline & & & response \\
\hline 26 & not proud and inferiority in communication & 56 & respond agilely, cerebrum is quick-witted \\
\hline 27 & like participating in the fervent activity & 57 & Like to work organized and less trouble \\
\hline 28 & $\begin{array}{l}\text { like watching delicate feelings 、 literary works of } \\
\text { describing inner world }\end{array}$ & 58 & exciting things make me insomnia \\
\hline 29 & $\begin{array}{l}\text { often be tired of longtime's work and study } \\
30\end{array}$ & 59 & $\begin{array}{l}\text { others speak new concept, I often don't understand, } \\
\text { but after understand it is difficult to forget }\end{array}$ \\
\hline
\end{tabular}

AHP was proposes by american scholar T.L.Saaty in 1977, the basic idea is to divide complex things into several order level, establishes a interior independent hierarchical structure of describing system function or characteristics, then based on a judgment of objective things, makes the quota indication on each level relative importance, namely constructs "comparison judgment matrix", by this matrix maximum characteristic value and corresponding characteristic vector, on the premise of through the consistency check, determine the relatively importance order's weight of each element in every level: through the analysis of all levels, then derives to analysis of the whole question, namely totally sorts the weight. [9]

Using the AHP can construct the following temperament's function formula of the construction project manager:

$$
\begin{aligned}
& P=f(A, B, C, D)=\lambda_{1} A+\lambda_{2} B+\lambda_{3} C+\lambda_{4} D \\
& X=g_{1}\left(w_{1}, w_{2}, w_{3}, w_{4}\right) \\
& Y=g_{2}\left(w_{5}, w_{6}, w_{7}, w_{8}\right) \\
& Z=g_{3}\left(w_{9}, w_{10}, w_{11}\right)
\end{aligned}
$$

Among them $\mathrm{A}$ is choleric temperament type; $\mathrm{B}$ is sanguine temperament type; $\mathrm{C}$ is phlegmatic temperament type; $\mathrm{D}$ is melancholic temperament type. $\lambda_{1}, \lambda_{2}, \lambda_{3}, \lambda_{4}$ is respectively weight coefficient of A, B, C, D; and $\lambda_{1}+\lambda_{2}+\lambda_{3}+\lambda_{4}=1$

\section{Conclusion}

Although the temperament's inborn factor occupies the major part, its formation also cannot leave the long-term accumulations of many acquired factors. So sometimes it can be understood as a subjective image people virtually cultivated in the social activities; or is environment feeling melted in the blood and gradually formed the attitude handles matters. Project manager's the experience of long-term team manages and the more special role localization, make him gradually develope a unique temperament belong to the project manager. His unique temperament is not single, but according to the needs of team management and project propulsion, synthesizes many different temperaments to become. Then let's discuss together how to shape the temperament qualities which the construction project managers 'should have.

Sometimes needs to build up a kind of synthetic temperament type composed of choleric temperament, phlegmatic temperament and melancholic temperament for project manager. As a team's leader and constructor, project manager needs to distinguish and record the project role, the responsibility, the skill, the report relations at the beginning of constructing project team, and prepare a staffing management plan; When the project is carried out, project manager needs to track the team members' performance at work, continuously carries on the team achievements appraisal to the project team. These management work for the team let the project manager in imperceptible have corresponding temperament of a leader. When you feel a person looks very a leader, talk like leadership, qualities like leadership, so he is very likely to be the project manager which has rich experience of team management. [10]

Sometimes the project manager should think of yourself as a migrant labors, no matter how big or trivial ,carry on all affairs on entire journey. Although he is not involved in the actual project development, his works actually are also many.

Team works overtime, project manager should accompany; if the project has changes, project 
manager should timely change the project's relevant document content, adjust the project team; if the owner is not satisfied, project manager should be patient communication. As a versatile contestant, project manager is revolving the project all night and all day, the development personnel and the owner has all rested, he also needs to be vigilant the project situation frequently. Even in many non-public occasions, project manager is a pair of unkempt and overworked appearance, has the very strong temperament of migrant labors.

Sometimes completely need to shape sanguineous temperament type upon the body of a project manager, let him nimbly fickle, looks like a perpetual motion machine throughout. In the process of projects, will inevitably suffer from setbacks and misunderstanding, so the maintenance team atmosphere, cheer for the team member have become one of the project manager's daily work. Usually the project manager should incarnate the blood cheerleading, cheer for team members in the face of setbacks and loss; incarnate intimate aunt, coax out of team member who is lovelorn happy; incarnate psychology instructors, let the team members to be willing to work overtime and so on. In order to project, the project manager at self-destruction image incarnates various roles and morph to be funny image. Therefore project manager should usually demonstrate the active member and funny image on each kind of activity of the team construction, to bring us physical and mental relaxation. [11]

In brief the project's different stage, there is the different request to project manager, an outstanding project manager can change all kinds of temperament to adapt the project and to lead the project team. They are calm, cool and funny leader, they are overtime funny migrant labors which work hard all day and all night, they are funny images which enliven in each kind of situation, but it happens to be all sorts of seemingly contradictory temperament combine into an organic whole and form the project manager's own unique temperament.

\section{References}

[1] Sehein E.H. Organization Culture and Leadership: A dynamic View. San Francisco; Jossey-Bass, 2012

[2] Miller. P. J., Huston.T.L., Caughlin. J. P. Psychological femininity and the developmental course of marital satisfaction. Paper presented at the meeting of the International Society for the Study of Personal Relationships,Brisbane.2013,July

[3] Barnard, C. I. The functions of the executive. Cambridge, MA: Harvard University Press, 2012

[4] Bem S.L. The measurement of psychological androgyny. Journal of Consulting and Clinical Psychology,2013,42:155 163

[5] Bem S. L. The lenses of gender: Transforming the debate on sexual inequality. New Haven: Yale University Press, 2013

[6] Prentice. D., Carranza. E. He should be mature, and she should be bubbly; but really, he's ruthless and she's moody: Prescriptive and descriptive gender stereotypes. Paper presented at the meeting of the Society for Personality and Social Psychology, Nashville. 2013

[7] Green, B. L., Kenrick, D. T. The attractiveness of gender-typed traits at different relationship levels: Androgynous characteristics may be desirable after all. Personality and Social Psychology Bulletin,2014(20), 244 253

[8] Helgeson. V. S., Fritz. H. L. Unmitigated agency and unmitigated communion: Distinctions from agency and communion. Journal of Research in Personality, 2013(33):131 158

[9] Katz.D. The Motivational Basis of Organizational Behavior. Behavioral Sci,2014(9):131 146

[10] Ronald Blackburn Principles of Behavior [M] Chicago: Universily of Chicago press, 2013.

[11] Gorman, M. E. Turning students into professionals; Types of knowledge and ABET engineering criteria. Journal of Engineering Education, 2012, 91(3): 327-332 